\title{
Review: efficiency of physical and chemical treatments on the inactivation of dairy bacteriophages
}

\section{Daniela M. Guglielmotti, Diego J. Mercanti, Jorge A. Reinheimer and Andrea del L. Quiberoni *}

Instituto de Lactología Industrial, Universidad Nacional del Litoral - Consejo Nacional de Investigaciones Científicas y Técnicas, Santa Fe, Argentina

Edited by:

Michael Gänzle, Alberta Veterinary

Research Institute, Canada

\section{Reviewed by:}

Lorenza Putignani, Children's Hospital and Research Institute Bambino Gesù Hospital, Italy

Anderson De Souza Sant'Ana, University of São Paulo, Brazil

Min-Tze Liong, Universiti Sains

Malaysia, Malaysia

*Correspondence:

Andrea del L. Quiberoni, Instituto de Lactología Industrial, Universidad Nacional del Litoral - Consejo

Nacional de Investigaciones,

Científicas y Técnicas, Santiago del

Estero 2829, Santa Fe 3000,

Argentina.

e-mail: aquibe@fiq.unl.edu.ar
Bacteriophages can cause great economic losses due to fermentation failure in dairy plants. Hence, physical and chemical treatments of raw material and/or equipment are mandatory to maintain phage levels as low as possible. Regarding thermal treatments used to kill pathogenic bacteria or achieve longer shelf-life of dairy products, neither low temperature long time nor high temperature short time pasteurization were able to inactivate most lactic acid bacteria (LAB) phages. Even though most phages did not survive $90^{\circ} \mathrm{C}$ for $2 \mathrm{~min}$, there were some that resisted $90^{\circ} \mathrm{C}$ for more than $15 \mathrm{~min}$ (conditions suggested by the International Dairy Federation, for complete phage destruction). Among biocides tested, ethanol showed variable effectiveness in phage inactivation, since only phages infecting dairy cocci and Lactobacillus helveticus were reasonably inactivated by this alcohol, whereas isopropanol was in all cases highly ineffective. In turn, peracetic acid has consistently proved to be very fast and efficient to inactivate dairy phages, whereas efficiency of sodium hypochlorite was variable, even among different phages infecting the same LAB species. Both alkaline chloride foam and ethoxylated non-ylphenol with phosphoric acid were remarkably efficient, trait probably related to their highly alkaline or acidic $\mathrm{pH}$ values in solution, respectively. Photocatalysis using UV light and $\mathrm{TiO}_{2}$ has been recently reported as a feasible option to industrially inactivate phages infecting diverse $L A B$ species. Processes involving high pressure were barely used for phage inactivation, but until now most studied phages revealed high resistance to these treatments. To conclude, and given the great phage diversity found on dairies, it is always advisable to combine different anti-phage treatments (biocides, heat, high pressure, photocatalysis), rather than using them separately at extreme conditions.

Keywords: phage infection, dairy industry, heat treatments, biocides, high pressure, photocatalysis

\section{THE THREAT OF PHAGE INFECTIONS IN DAIRY INDUSTRY}

Phage infection is the most prevalent cause of decreased starter activity in cheese and fermented milks manufacturing, resulting in fermentations in which acid production is markedly reduced or, in extreme cases, blocked (Neve, 1996). Raw milk is considered to be the principal source of phages, either as free virions or as prophages present in wild strains of lactic acid bacteria (LAB) and constitutes the primary phage entranceway to the industrial environment (Everson, 1991; Josephsen and Neve, 1998). Phages are difficult to eliminate because they rapidly disseminate in dairy plants (Neve et al., 1989). As phage infections lead to economic losses in dairy factories, the development of control measures becomes essential.

This review is aimed to revise the information regarding the diverse treatments applied in dairy industry for sanitization and microbial inactivation, and their efficiency on the inactivation of bacteriophages present in the dairy environment.

\section{TRADITIONAL TREATMENTS I: HEAT TREATMENTS}

In dairy manufactures, raw milk is often subjected to a thermal treatment to eliminate the majority of microorganisms present, including spoilage and pathogens, thus assuring a good quality and longer shelf-life of the final product. Many works have studied thermal resistance of lactic acid bacteriophages, especially focusing on temperatures traditionally used to sanitize the milk in the dairy industry $\left(63,72\right.$, and $\left.90^{\circ} \mathrm{C}\right)$, and on conditions recommended by the International Dairy Federation (IDF; $90^{\circ} \mathrm{C}$ for $15 \mathrm{~min}$ ) to guarantee complete phage inactivation (Svensson and Christiansson, 1991). For cheese production, low temperature long time (LTLT, $63^{\circ} \mathrm{C}$ for $30 \mathrm{~min}$ ) or high temperature short time (HTST, $72^{\circ} \mathrm{C}$ for $15 \mathrm{~s}$ ) pasteurization were traditionally applied. Ultra-hightemperature (UHT) processing, also called ultra-pasteurization (more than $135^{\circ} \mathrm{C}$ for $1-2 \mathrm{~s}$ ), is a sterilization treatment as it produces spores destruction. However, this high heating can cause Maillard browning and negatively affect the taste and smell of dairy products. Milk used for yogurt production is generally treated at $80^{\circ} \mathrm{C}$ for $30 \mathrm{~min}$ or at $95^{\circ} \mathrm{C}$ for $10 \mathrm{~min}$ (Soukoulis et al., 2007). Regardless of the high efficiency of this heat treatment to inactivate microorganisms, it is not always effective against dairy bacteriophages.

Thermal treatments produce morphological changes on phage particles. The effects of such treatments were monitored by transmission electron microscopy on a heat-sensitive and on a heatresistant Lactococcus lactis phage by Atamer et al. (2010). Release 
of phage DNA from viral capsids, decomposition of phage into head and tail structures, and aggregation of phage tails were the most frequently seen phenomena, principally for the heat-sensitive phage studied. For the heat-resistant one, changes in phage morphology were less evident. These authors concluded that heat resistance is associated with both increased stability of viral DNA packaged in the capsids and enhanced stability of phage particles as a whole.

Certain parameters are calculated in order to evaluate phage susceptibility against heat treatments. One of the most used is $T_{99}$, defined as the time to achieve $99 \%$ inactivation of phage particles, which allows having a very good approximation of phage resistance against inactivation treatments. However, this parameter does not consider total phage destruction, but inactivation of the most sensitive $99 \%$ of phage population. Whether a heat treatment is applied to samples containing elevated initial phage loads, remaining viral particles can multiply and reach problematic levels again. With this regard, the minimum time necessary for complete phage inactivation (considering it when phage counts become undetectable in the treated samples) becomes another useful parameter. This time may be much longer than the corresponding $T_{99}$ and, ideally, both parameters should be determined.

Table 1 overviewed the susceptibility to 63,72 , and $90^{\circ} \mathrm{C}$ treatments (expressed as $T_{99}$ values) of some bacteriophages from lactic acid/probiotic bacteria of great importance in fermentative dairy industry. Regardless the thermal treatment applied, a great diversity in heat susceptibility has been observed. Consequently, thermal resistance would depend more on the particular phage studied than on the species specificity. For instance, some bacteriophages specific of L. lactis and Streptococcus thermophilus were rapidly inactivated at $63^{\circ} \mathrm{C}\left(T_{99}\right.$ values from 2.7 to $\left.12 \mathrm{~min}\right)$, whereas some other phages infecting these species revealed high resistance to the same or even harsher treatments (Binetti and Reinheimer, 2000; Suárez and Reinheimer, 2002). Low thermal resistance is not confined to phages infecting dairy cocci ( L. lactis and S. thermophilus); a variety of Lactobacillus phages with an extremely heat sensitivity was also discovered. Among the latter, it is worth noticing phages hv (Lactobacillus helveticus), Cb1/204 (Lactobacillus delbrueckii), PL-1 and J-1 (Lactobacillus casei and Lactobacillus paracasei), which showed very low $T_{99}$ values (from 2.1 to $3.1 \mathrm{~min}$ ) in all suspension media tested (Quiberoni et al., 1999; Capra et al., 2004; Ebrecht et al., 2010). In spite of the high heat sensitivity to $63^{\circ} \mathrm{C}$ shown by some Lactobacillus phages, there were others capable to easily resist this treatment, as demonstrated by Lactobacillus plantarum phages investigated by Briggiler Marcó et al. (2009) ( $T_{99}$ values $\left.>45 \mathrm{~min}\right)$.

As it can be deduced, increasing the temperature from 63 to $72^{\circ} \mathrm{C}$ improved the efficiency of phage inactivation. Still, numerous phages tested were able to resist this higher temperature. Good examples are phages 001 (L. lactis), 0BJ and CYM (S. thermophilus), CNRZ 832-B1 (Lb. helveticus), Ib 3 (Lb. delbrueckii subsp. lactis), ATCC 8014-B2 and FAGK1 (Lb. plantarum), showing high $T_{99}$ values after incubation at $72^{\circ} \mathrm{C}$. Sometimes, even if $T_{99}$ values were not so elevated (e.g., $2.5 \mathrm{~min}$ for phage $\mathrm{Ib}_{3}$ ), the time to destroy the total viral population was much longer ( $>45 \mathrm{~min})$. In these cases, inactivation curves might be fitted into two or even three independent linear components (Daoust et al., 1965). Attempts to explain this behavior suggested that a mixture of phage particles with different heat sensitivity might exist: a rapidly inactivated population, responsible for the low $T_{99}$

Table 1 | Susceptibility of dairy phages to heat treatments, using reconstituted skim milk as suspension media.

\begin{tabular}{|c|c|c|c|c|c|}
\hline \multirow[t]{2}{*}{ Phage } & \multirow[t]{2}{*}{ Species } & \multicolumn{3}{|c|}{$T_{99}{ }^{a}$} & \multirow[t]{2}{*}{ Reference } \\
\hline & & $63^{\circ} \mathrm{C}$ & $72^{\circ} \mathrm{C}$ & $90^{\circ} \mathrm{C}$ & \\
\hline MLC-A & Lactobacillus casei and Lactobacillus paracasei & $>45$ & 2.6 & $<2$ & Capra et al. (2006) \\
\hline MLC-A2 & & n.d. & n.d. & 5 & Capra et al. (2009a) \\
\hline $\mathrm{J}-1$ & & 3.1 & $<5$ & $<5$ & Capra et al. (2004) \\
\hline OBJ & Streptococus thermophilus & $>45$ & 12.0 & $<5$ & Binetti and Reinheimer (2000) \\
\hline $021-5$ & & 30 & 1.5 & $<5$ & \\
\hline $\mathrm{lb}_{3}$ & Lactobacillus delbrueckii & $>45$ & 2.9 & $<5$ & Quiberoni et al. (2003) \\
\hline YAB & & 45.0 & $<2$ & $<5$ & \\
\hline $\mathrm{LL}-\mathrm{H}^{\mathrm{b}}$ & & 6.2 & $<5$ & $<5$ & \\
\hline FAGK1 & Lactobacillus plantarum & $>45$ & 11.7 & $<5$ & Briggiler Marcó et al. (2009) \\
\hline ATCC 8014-B1 & & $>45$ & 7.2 & $<5$ & \\
\hline CNRZ 832-B1 ${ }^{\mathrm{C}}$ & Lactobacillus helveticus & $>45$ & 21.1 & $<5$ & Quiberoni et al. (1999) \\
\hline$h v^{d}$ & & 2.2 & $<2$ & $<5$ & \\
\hline 001 & Lactococcus lactis & $>45$ & 20.0 & $<5$ & Suárez and Reinheimer (2002) \\
\hline QF12 & & 2.7 & 1.5 & $<5$ & \\
\hline
\end{tabular}

Time (min) to achieve 99\% inactivation of phage particles.

${ }^{b}$ Alatossava and Pythilä (1980)

'Séchaud et al. (1992)

'Kiuru and Tybeck (1955)

n.d., Not determined. 
values obtained, and a heat-resistant one, explaining the long time required for total phage inactivation. Both populations would follow a first-order reaction, but with a decreased slope for the latter (Hiatt, 1964). It has been suggested that heat-resistant phages naturally occur in all types of dairy environments as a low proportion of the whole phage population (Atamer et al., 2009). This fact remarks the importance of consider both parameters when defining the heat sensitivity of a given phage. Similarly to phage $\mathrm{Ib}_{3}$, destruction of total viral populations for the above mentioned heat-resistant phages was generally not achieved at this temperature, since detectable viable phage particles were found even after $45 \mathrm{~min}$ of treatment, which is a much longer period than that normally applied in the dairy industry for milk sanitization (Quiberoni et al., 1999, 2003; Binetti and Reinheimer, 2000; Suárez and Reinheimer, 2002; Briggiler Marcó et al., 2009). Dissimilar susceptibility to short-time pasteurization conditions $\left(72^{\circ} \mathrm{C}\right.$ for $30 \mathrm{~s}$ ) was found for two Lactococcus phages; whereas one of them was complete and rapidly inactivated (loss of 7 log orders), the other one was highly heat-resistant (reduction of 2 log orders) and remained viable even after $60 \mathrm{~min}$ of treatment (Müller-Merbach et al., 2005). Figure 1 shows thermal inactivation kinetics at $72^{\circ} \mathrm{C}$ of some dairy bacteriophages, when reconstituted skim milk (RSM) was used as suspension media.

In most cases, temperatures higher than $72-75^{\circ} \mathrm{C}$ allowed efficient phage inactivation in a short time. Since milk destined to yogurt manufacture is usually treated at $82^{\circ} \mathrm{C}$ for $5 \mathrm{~min}$, some authors have subjected $L b$. delbrueckii phage particles to this temperature (Ebrecht et al., 2010), finding total phage destruction within 2 min of treatment. Similarly, Müller-Merbach et al. (2005) treated lactococcal phages $\mathrm{P} 001$ and $\mathrm{P} 008$ to $80^{\circ} \mathrm{C}$, demonstrating undetectable counts after only $1 \mathrm{~min}$ at this temperature. On the contrary, $40 \%$ of $L$. lactis phages tested were able to resist $80^{\circ} \mathrm{C}$ for $5 \mathrm{~min}$ (Atamer et al., 2009), whereas $70 \%$ of Leuconostoc phages particles were still detectable after $1 \mathrm{~min}$ at this temperature (Atamer et al., 2011). Until recently, heat treatment at $90^{\circ} \mathrm{C}$ for $5 \mathrm{~min}$ was sufficient for inactivation of phage particles (Binetti and Reinheimer, 2000; Suárez and Reinheimer, 2002; Capra et al., 2004; Briggiler Marcó et al., 2009). Despite this, in the last years some extraordinarily heat-resistant phages are being found in many research laboratories, such as phage $\mathrm{Ib}_{3}$ ( $\mathrm{Lb}$. delbrueckii), whose complete inactivation required at least $15 \mathrm{~min}$ at $90^{\circ} \mathrm{C}$ (Quiberoni et al., 2003). In the same way, $30 \mathrm{~min}$ were necessary to destroy five $L b$. paracasei phages at that temperature (Capra et al., 2009a). Moreover, some lactococcal phages were able to survive $5 \mathrm{~min}$ at $90^{\circ} \mathrm{C}$ (Buzrul et al., 2007), whereas Atamer et al. (2009) revealed that phage P1532 was still detectable even after heating at either $90^{\circ} \mathrm{C}$ for $20 \mathrm{~min}$ or $97^{\circ} \mathrm{C}$ for $5 \mathrm{~min}$. The protocol used for microbiological detection of phages in dairy samples includes a heat treatment at $90^{\circ} \mathrm{C}$ for $15 \mathrm{~min}$ of control samples to be tested for non-phage inhibiting agents (Svensson and Christiansson, 1991). However, this standard protocol might not be appropriate for inactivating high heat-resistant phages (Atamer et al., 2009). Furthermore, the number of phages with exceptional thermo-resistance seems to be increasing every day, which led to the need of revising the methodology applied to industrial samples suspected of containing phages.

Thermal susceptibility of phages can differ according to the suspension media used. However, dissimilar results impeded an agreement about the most protective one. In some cases, milk

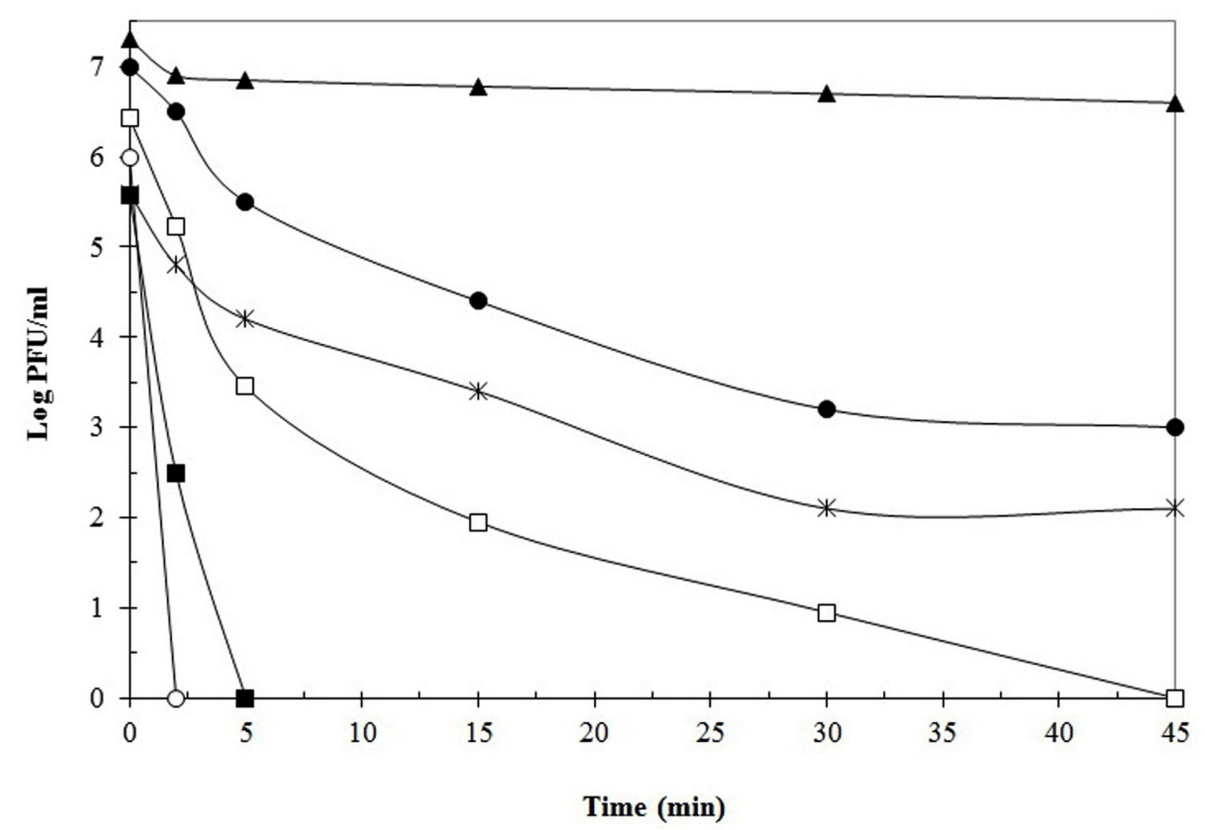

FIGURE 1 |Thermal destruction kinetics of phages $\mathrm{Ib}_{3}(\square)$, LL-H

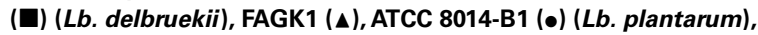
$021-5(\circ)$, and $\mathrm{OBJ}(*)$ (S. thermophilus), at $72^{\circ} \mathrm{C}$ using reconstituted skim milk as suspension media. Data adapted from Binetti and Reinheimer (2000), Quiberoni et al. (2003), and Briggiler Marcó et al. (2009). 
seemed to be protective to viral particles, as observed for those of $L b$. delbrueckii tested by Quiberoni et al. (2003), in comparison to MRS broth and TMG buffer. Similar conclusions were obtained by other authors when testing either Lactococcus or Leuconostoc phages (Atamer et al., 2009, 2010, 2011). The reason for the protective effect of milk is still being investigated; however, it was postulated that certain components, especially casein, could be responsible for the increased thermal resistance of dairy phages. Unlike protein, fat was found to have no influence on phage inactivation (Atamer et al., 2010). Protective effect of milk, however, was not always verified. For example, Suárez and Reinheimer (2002) determined that phosphate buffer was the most protective medium in comparison with M17-broth and skim milk. Sometimes, it was not possible to establish a clear influence of the suspension media. Some $L b$. helveticus phages, for example, resisted better in MRS broth, but others did it in TMG buffer (Quiberoni et al., 1999). Likewise, not conclusive influence was found by Capra et al. (2004) when analyzing Lb. casei and $L b$. paracasei phages.

\section{TRADITIONAL TREATMENTS II: BIOCIDES}

A biocide should fulfill several criteria to be usable in the food industry, for example possessing a fast antimicrobial activity, ease of application, low cost, lack of negative impact on the final product, and degradation into harmless final products (Nicholds and Wolf, 1945; Schröder, 1984). However, inactivation of bacteriophages was taken into consideration only recently as a criterion of biocides selection, which is reflected by an increasing number of studies directed to quantify their effectiveness in this sense. Many of these works were carried out in our laboratory and biocides tested were, until recently, almost exclusively ethyl alcohol (ethanol), isopropyl alcohol (isopropanol), sodium hypochlorite, and peracetic acid, all of which will be further discussed. Table 2 summarizes sensitivity (expressed as $T_{99}$ ) of phages of diverse bacterial species to ethanol and sodium hypochlorite used at different concentration.

Ethanol and, at much lesser extent, isopropanol, were tested on a broad spectrum of LAB phages, at concentrations oscillating between 10 and $100 \%(\mathrm{v} / \mathrm{v})$, but the lower concentration did

Table 2 |Time ( $\mathrm{min}$ ) necessary to reach $99 \%$ inactivation $\left(T_{99}\right)$ of phages infective for diverse species of lactic acid bacteria in presence of ethanol and sodium hypochlorite at different concentration.

\begin{tabular}{|c|c|c|c|c|c|c|c|c|c|c|c|}
\hline \multirow[t]{2}{*}{ Phage } & \multirow[t]{2}{*}{ Species } & \multicolumn{4}{|c|}{ Ethanol (\% v/v) } & \multicolumn{5}{|c|}{ Sodium hypochlorite (ppm) } & \multirow[t]{2}{*}{ Reference } \\
\hline & & 10 & 50 & 75 & 100 & 100 & 200 & 300 & 400 & 800 & \\
\hline $021-4$ & Streptococcus thermophilus & $>45$ & 18 & 1.5 & $>45$ & $<5$ & n.d. & n.d. & n.d. & n.d. & Binetti and Reinheimer (2000) \\
\hline $021-5$ & & $>45$ & 45 & 3.5 & 5.3 & $<5$ & n.d. & n.d. & n.d. & n.d. & \\
\hline OBJ & & 45 & 3.5 & 1.8 & 1.8 & $<5$ & n.d. & n.d. & n.d. & n.d. & \\
\hline 031-D & & $>45$ & 2.1 & 2.1 & 3.5 & $<5$ & n.d. & n.d. & n.d. & n.d. & \\
\hline CYM & & $>45$ & 45 & 2.4 & 3.2 & $<5$ & n.d. & n.d. & n.d. & n.d. & \\
\hline 001 & Lactococcus lactis & $>45$ & $>45$ & 18.5 & 1.9 & $<5$ & n.d. & n.d. & n.d. & n.d. & Suárez and Reinheimer (2002) \\
\hline 046 & & $>45$ & $>45$ & $>45$ & 24.3 & 32.7 & 4 & 2.7 & n.d. & n.d. & \\
\hline QF12 & & $>45$ & $>45$ & 4.9 & 3.6 & $<5$ & n.d. & n.d. & n.d. & n.d. & \\
\hline QP4 & & $>45$ & $>45$ & 1.3 & 3.8 & 8.5 & 3.1 & n.d. & n.d. & n.d. & \\
\hline BYM & Lactobacillus delbrueckii & $>45$ & $>45$ & 8.4 & 2.5 & 13 & 3 & 1.9 & 1.7 & n.d. & Quiberoni et al. (2003) \\
\hline YAB & & $>45$ & $>45$ & 7.6 & 1.8 & 8.7 & 6.5 & 2.8 & 2.2 & n.d. & \\
\hline $\mathrm{Ib}_{3}$ & & $>45$ & $>45$ & $>45$ & 22.2 & $>45$ & $>45$ & $>45$ & $>45$ & 2.3 & \\
\hline LL-H & & $>45$ & $>45$ & 7.4 & 4.8 & 8.1 & 2.5 & 2.5 & 2 & n.d. & \\
\hline Cb1/204 & & $>45$ & $>45$ & $>45$ & 2 & 1.3 & $<1$ & n.d. & n.d. & n.d. & Ebrecht et al. (2010) \\
\hline Cb1/342 & & $>45$ & $>45$ & $>45$ & 24.9 & 1.9 & 1.4 & $<1$ & n.d. & n.d. & \\
\hline CNRZ 832-B1 & Lactobacillus helveticus & 14.7 & $<2$ & $<2$ & $<2$ & $<10$ & n.d. & n.d. & n.d. & n.d. & Quiberoni et al. (1999) \\
\hline CNRZ 0241 & & $>45$ & $<2$ & $<2$ & $<2$ & $<5$ & n.d. & n.d. & n.d. & n.d. & \\
\hline hv & & $>45$ & 7.2 & 2.2 & 7.2 & $<5$ & n.d. & n.d. & n.d. & n.d. & \\
\hline ATCC 15807-B1 & & $>45$ & 2.2 & $<2$ & 2.8 & $<10$ & n.d. & n.d. & n.d. & n.d. & \\
\hline ATCC 8014-B1 & Lactobacillus plantarum & $>45$ & 8.3 & 29 & 3.7 & n.d. & $>45$ & n.d. & 2.5 & 1.8 & Briggiler Marcó et al. (2009) \\
\hline ATCC 8014-B2 & & $>45$ & 14.8 & 44.6 & 7.4 & n.d. & $>45$ & n.d. & 4.3 & 1.8 & \\
\hline FAGK1 & & $>45$ & 11.4 & 41.6 & 5 & n.d. & $>45$ & n.d. & 2.6 & 1.9 & \\
\hline FAGK2 & & $>45$ & 14.7 & $>45$ & 7.3 & n.d. & $>45$ & n.d. & 4.2 & 1.6 & \\
\hline PL-1 & Lactobacillus casei and & $>45$ & $>45$ & 9.7 & 10.3 & n.d & n.d & n.d & 26.8 & $<5$ & Capra et al. (2004) \\
\hline $\mathrm{J}-1$ & Lactobacillus paracasei & $>45$ & $>45$ & 5.5 & 9 & n.d & n.d & n.d & 20.6 & $<5$ & \\
\hline MLC-A & & $>45$ & $>45$ & 1.8 & $>45$ & n.d & 27.8 & n.d & 9.2 & n.d & Capra et al. (2006) \\
\hline iLp84 & & $>45$ & $>45$ & 15.5 & $>45$ & $>45$ & n.d & n.d. & 13.1 & $<2$ & Mercanti et al. (2012) \\
\hline iLp1308 & & $>45$ & $>45$ & 9.6 & $>45$ & $>45$ & n.d & n.d. & $<2$ & $<2$ & \\
\hline
\end{tabular}

n.d. Not determined. 
not produce in general any visible effect. Thus, only $50 \%(\mathrm{v} / \mathrm{v})$ or higher concentrations will be considered for discussion from now on. With respect to isopropanol, it was tested on phages of L. lactis (Suárez and Reinheimer, 2002), S. thermophilus (Binetti and Reinheimer, 2000), Lb. delbrueckii (Quiberoni et al., 2003; Ebrecht et al., 2010), Lb. casei and Lb. paracasei (Capra et al., 2004, 2006), and Lb. plantarum (Briggiler Marcó et al., 2009). In all cases, inactivation was almost undetectable and required very long incubation periods (generally $>45 \mathrm{~min}$ ), with only a few exceptions (lactococcal phage 001, Lb. delbrueckii phage LL-H, and S. thermophilus phage 031-D) where a milder effect was observed. Consequently, the biocide efficiency of isopropanol will not be subsequently debated.

Streptococcus thermophilus phages CYM, 021-4, 021-5, 0BJ, and 031-D showed a moderate sensitivity to ethanol, as viral counts were $99 \%$ reduced ( $T_{99}$ ) after less than 5 min of incubation in $75 \%$ (v/v) ethanol (optimal concentration), and became undetectable after $15 \mathrm{~min}$ of contact with either 75 or $100 \%(\mathrm{v} / \mathrm{v})$ concentrations. An exception was phage $021-4$, which greatly resisted $100 \%$ (v/v; $>45 \mathrm{~min}$; Table 2), although being highly sensitive to $75 \%$ (v/v) ethanol (Binetti and Reinheimer, 2000). Lactococcal phages were, instead, more affected by pure ethanol than by 50 or $75 \%$ $(\mathrm{v} / \mathrm{v})$ dilutions, with the exception of phage $\mathrm{QP} 4$, which possesses a very low resistance to $75 \%(\mathrm{v} / \mathrm{v})$ ethanol. As a group, Lb. helveticus phages were the most sensitive to ethanol treatments of all studied LAB phages. Collection phages CNRZ 832-B1 and CNRZ 0241 were inactivated by $50 \%(\mathrm{v} / \mathrm{v})$ ethanol after $5 \mathrm{~min}$ of incubation. Curiously, the former was moderately affected by a concentration of as low as $10 \%(\mathrm{v} / \mathrm{v})$ ethanol, being the only phage with a reported $T_{99}$ lower than $45 \mathrm{~min}$ for such concentration (Table 2). Phages hv and ATCC 15807-B1, instead, were more sensitive to a higher concentration (75\% v/v) (Quiberoni et al., 1999). Lb. delbrueckii phages, either of virulent (Quiberoni et al., 2003) or temperate (Ebrecht et al., 2010) nature, were most sensitive to $100 \%$ (v/v) ethanol, and showed dissimilar $T_{99}$ values at this concentration, ranging from $22.2 \mathrm{~min}$ for phage $\mathrm{Ib}_{3}$ (the most resistant) to $2 \mathrm{~min}$ or less for phages YAB and temperate phage Cb1/204 (Table 2). In turn, LL-H was the only $L b$. delbrueckii phage completely inactivated after $30 \mathrm{~min}$ in $75 \%$ (v/v) ethanol (Quiberoni et al., 2003). Interestingly, temperate phages $\mathrm{Cb} 1 / 204$ and $\mathrm{Cbl} / 342$ presented lower $T_{99}$ values than 3 out of the 4 virulent phages studied (Table 2). Concerning either virulent phages PL-1, J-1 (Capra et al., 2004), and MLC-A (Capra et al., 2006), or temperate phages iLp84 and iLp1308 (Mercanti et al., 2012), all infective for Lb. casei and $L b$. paracasei, a similar pattern of inactivation was obtained after incubation with ethanol: a fast initial reduction of about two-log orders was followed by a plateau, yielding almost the same phage titers after 15 or 45 min of treatment. For all $L b$. casei and Lb. paracasei phages, best inactivation was achieved at $75 \%(\mathrm{v} / \mathrm{v})$. Finally, Lb. plantarum phages were only slightly inactivated with $100 \%$ (v/v; the best concentration) or $50 \%(\mathrm{v} / \mathrm{v})$ ethanol, and almost not affected by $75 \%(\mathrm{v} / \mathrm{v})$, which is optimal for many other LAB phages (Briggiler Marcó et al., 2009). Apart from this peculiarity, inactivation rates were similar between $L b$. casei or $L b$. paracasei and $L b$. plantarum phages.

With respect to the mechanism of action of ethanol, a study conducted by Maillard et al. (1996a) showed capsid alterations on
F116, a phage infective for Pseudomonas aeruginosa; as expected, no DNA damage was evidenced. The antibacterial attribute of alcohols is mainly due to alterations on the lipid fraction of the plasmatic membrane. For this reason, naked phages are likely to be naturally more resistant than bacteria to ethanol challenging.

To sum up, it can be concluded that there are three levels of phage sensitivity to ethanol. In general, the most susceptible (though moderately) phages were those infecting dairy cocci: L. lactis and S. thermophilus. Among lactobacilli, Lb. helveticus were readily inactivated as well. In the middle are placed phages infecting $L b$. delbrueckii, with dissimilar resistance showed by different phages. Finally, phages infecting Lb. plantarum, Lb. casei and $L b$. paracase $i$ were highly resistant to ethanol treatments. In general, the efficiency of phage inactivation accomplished by ethanol, though superior than that of isopropanol, is still not sufficient for industrial applications. Besides, the absence of an optimal ethanol concentration able to kill a broad range of dairy phages makes this compound unsuitable as an anti-phage strategy in the dairy industry.

Resistance to sodium hypochlorite of phages infective for diverse LAB genera resembles that exhibited against ethanol. Firstly, Lb. helveticus, L. lactis, and S. thermophilus phage particles were completely eliminated by a concentration of residual free chlorine as low as 100 ppm (Quiberoni et al., 1999; Binetti and Reinheimer, 2000; Suárez and Reinheimer, 2002); only L. lactis phages 046 and QP4 required a stronger inactivation treatment ( 300 ppm for $45 \mathrm{~min}$ and $200 \mathrm{ppm}$ for $30 \mathrm{~min}$, respectively; Suárez and Reinheimer, 2002). On the other hand, two temperate $L b$. delbrueckii phages (Ebrecht et al., 2010) were readily killed as well. However, likewise for ethanol inactivation, there were other $L b$. delbrueckii phages with a noticeably greater resistance (BYM, YAB, and LL-H), requiring between 5 and $45 \mathrm{~min}$ in the presence of $400 \mathrm{ppm}$ of residual free chlorine (Quiberoni et al., 2003) for complete inactivation. Special attention deserves Lb. delbrueckii phage $\mathrm{Ib}_{3}$. Unexpectedly, it exhibited the highest phage resistance to sodium hypochlorite ever measured, requiring a minimal concentration of $1200 \mathrm{ppm}$ of residual free chlorine for at least $45 \mathrm{~min}$ for complete inactivation; this fact has been attributed to a long persistence of the phage in industrial environments (Quiberoni et al., 2003). As regards of $L b$. plantarum and $L b$. case $i, L b$. paracasei phages, all exhibited similar resistance to sodium hypochlorite. For four $L b$. plantarum phages, exposures of $15 \mathrm{~min}$ (phage ATCC 8014-B2) and $30 \mathrm{~min}$ (phages ATCC 8014$\mathrm{B} 1, \mathrm{FAGK} 1$, and FAGK2) to $800 \mathrm{ppm}$ of residual free chlorine were necessary to completely inactivate phage suspensions (Briggiler Marcó et al., 2009). Similarly, Capra et al. (2004) reported a minimum incubation of $5 \mathrm{~min}$ at $800 \mathrm{ppm}$ of residual free chlorine as necessary to completely inactivate $L b$. casei and $L b$. paracasei phage suspensions, whereas Mercanti et al. (2012) reported dissimilar results from one temperate $L b$. paracasei to another: a concentration of $400 \mathrm{ppm}$ was able to quickly eliminate i $L p 1308$, but $30 \mathrm{~min}$ at $800 \mathrm{ppm}$ were necessary for complete inactivation of $\mathrm{i} L p 84$, even though a $T_{99}<2$ min was calculated for the latter (Table 2). As $800 \mathrm{ppm}$ of free chlorine is a concentration perceptively higher than that permitted in the dairy industry (Briggiler Marcó et al., 2009), chlorine could be usable only at laboratory scale for the inactivation of $L b$. plantarum, $L b$. casei and $L b$. paracasei phages. 
According to some studies, sodium hypochlorite would cause phage inactivation through aggregation of tail proteins (Maillard et al., 1998), in addition to several structural alterations to the bacteriophage capsid; which is likely to be related to the release of phage DNA into the external medium. Overall, sodium hypochlorite could be regarded as a good (but not excellent) choice for industrial phage inactivation. It was quite effective for most challenged phages, but there are some of them which resisted biocide concentrations much greater than those permitted in an industrial sanitization process.

Peracetic acid (also known as ethaneperoxoic acid or peroxyacetic acid) is commercially available in the form of a mixture containing acetic acid, hydrogen peroxide, peracetic acid, and water in a quaternary equilibrium (Gehr et al., 2003). With regard to its use in the dairy industry, it has been widely documented as the best practical agent for phage inactivation. Its major advantages include its ability to efficiently inactivate most microorganisms, its resistance to catalase and peroxidase (enzymes which break down hydrogen peroxide) and its degradation into environmentally friendly products (acetic acid and hydrogen peroxide). Peracetic acid maintains its activity over a wide temperature $\left(0-40^{\circ} \mathrm{C}\right)$ and $\mathrm{pH}(3.0-7.5)$ ranges and in hard water, and is not affected by protein residues. These characteristics allow to safely use it in the food industry and even for cleaning-in-place (CIP) practices. Concerning the virucidal activity of peracetic acid, there are many works reporting a fast and effective inactivation of a broad spectrum of LAB phages, including phages infecting S. thermophilus (Binetti and Reinheimer, 2000), L. lactis (Suárez and Reinheimer, 2002), and several species of dairy lactobacilli, including $\mathrm{Lb}$. delbrueckii (Quiberoni et al., 2003; Ebrecht et al., 2010), Lb. helveticus (Quiberoni et al., 1999), Lb. plantarum (Briggiler Marcó et al., 2009), Lb. casei and Lb. paracasei (Capra et al., 2004, 2006; Mercanti et al., 2012). In addition, this chemical proved to be effective for the inactivation of non-LAB phages, such as $P$. aeruginosa phage F116 (Maillard et al., 1993). In all cases, a treatment of $5 \mathrm{~min}$ (or 2 min in some cases) at $40^{\circ} \mathrm{C}$ was enough to drop phage counts to undetectable levels, even of phages highly resistant to other chemical or thermal treatments, such as $L b$. delbrueckii phage $\mathrm{Ib}_{3}$ (Ebrecht et al., 2010). Peracetic acid is normally used at a concentration of $0.15 \%(\mathrm{v} / \mathrm{v})$ in water; the low $\mathrm{pH}$ of this aqueous solution (around 2) has been suggested to be responsible for phage inactivation (Mercanti et al., 2012). Schröder (1984) proposed $40^{\circ} \mathrm{C}$ as the most effective temperature to inactivate bacteria, yeasts, and fungi using peracetic acid. However, effectiveness for the inactivation of Lb. plantarum (Briggiler Marcó et al., 2009), Lb. casei and Lb. paracasei (Mercanti et al., 2012) phages was found to be similar at either 25 or $40^{\circ} \mathrm{C}$, thus recommending the use of this temperature for industrial convenience. Peracetic acid exerts its action through the hydroxyl radical $(\cdot \mathrm{OH})$, which reacts with any oxidizable compound present in its neighborhood, damaging practically any kind of macromolecule associated with a microorganism and eventually leading to its death. Complete rupture of the nucleic acid is accomplished during bacteriophage inactivation, but whether it occurs inside the capsid or after the DNA is released due to a capsid structural damage remains unclear. Such alteration of the capsid structure was observed by SDS-polyacrylamide gel electrophoresis (Maillard et al., 1996a,b).
There are several new biocides that are being progressively used by the dairy industry. Among these, it is worth mentioning: (i) quaternary ammonium chloride, (ii) peracetic and peroctanoic acids with hydrogen peroxide (Vortexx; Ecolab, 2011), (iii) an alkaline chloride foam (Active CL), (iv) p-toluenesulfonchloroamide, sodium salt (Clorina F; Cibsa, 2011), and (v) ethoxylated nonylphenol with phosphoric acid. However, very scarce data about their efficiency on LAB phages inactivation are available so far, with reports only on $L b$. delbrueckii (Ebrecht et al., 2010), Lb. casei and $L b$. paracasei (Mercanti et al., 2012) phages. Phage-killing activity was rather variable among these chemicals. Both alkaline chloride foam or ethoxylated nonylphenol with phosphoric acid were exceptionally efficient, which could be attributable to their extreme $\mathrm{pH}$ values ( $>12$ and $<2$, respectively); phages of species were not detected after 2 min of treatment (Ebrecht et al., 2010; Mercanti et al., 2012). Quaternary ammonium chloride proved to be a usable biocide as well, but its efficiency quickly diminished at concentrations slightly under the optimal recommended, especially for Lb. delbrueckii phages (Ebrecht et al., 2010). Lb. casei and $L b$. paracasei phages were more sensitive to low concentrations of quaternary ammonium chloride, but also in this case its effectiveness differed among the two phages studied (Mercanti et al., 2012). On the contrary, $p$-toluensulfonchloroamide showed no reduction on phage numbers, even when this compound was utilized without dilution and for longer incubation times, up to $2 \mathrm{~h}$ on $\mathrm{Lb}$. casei and $L b$. paracasei phages (Mercanti et al., 2012).

In turn, very different inactivation rates were observed between Lb. delbrueckii, Lb. casei and $L b$. paracasei phages when using Vortexx. Whereas all the Lb. delbrueckii phages studied were thoroughly inactivated by $0.13 \%(\mathrm{v} / \mathrm{v})$ Vortexx [with the exception of phage $\mathrm{Ib}_{3}$, which was only inactivated by a concentration of 0.26\% (v/v); Ebrecht et al., 2010], this biocide failed to produce any evident reduction on $L b$. casei and $L b$. paracase $i$ phage counts at a concentration of $0.26 \%(\mathrm{v} / \mathrm{v})$ (Mercanti et al., 2012). Vortexx is publicized as a novel product with excellent sanitizing results at room temperature and delivering wide antimicrobial activity, including yeasts, mold, and bacteria, at much lower concentration than peracetic acid used alone (Ecolab, 2011). This lower peracetic acid concentration raises the $\mathrm{pH}$ of Vortexx (at the recommended concentration of use) to values between 3.1 and 3.4. Unfortunately, this higher $\mathrm{pH}$ appears to be critical for the inactivation of some phages, as both i $L p 84$ and i $L p 1308$ were quick and completely inactivated by $0.15 \%(\mathrm{v} / \mathrm{v})$ peracetic acid, whilst $0.26 \%(\mathrm{v} / \mathrm{v})$ Vortexx yielded no significant titer reductions after $20 \mathrm{~min}$ of incubation (Mercanti et al., 2012).

\section{INSIGHTS TO NEW INACTIVATION TREATMENTS PHOTOCATALYSIS}

Raw milk is regarded as one of the main sources of phages, thus representing their most important way of entry to the industrial environment (Everson, 1991; Josephsen and Neve, 1998). Moreover, the capability of bacteriophages to remain in the air for long periods makes bioaerosols one of the most important dispersion routes of virions. Unfortunately, none of the currently available technologies is appropriate to inactivate bacteriophages suspended in the air of dairies, either in laboratory or in processing plants (Quiberoni et al., 1999, 2004, 2006). 
The photocatalytic properties of $\mathrm{TiO}_{2}$ have been the subject of much research, mainly for the photochemical pollutant oxidation. Several advantages of photocatalysis make this methodology an excellent alternative to the traditional chemical disinfection: (i) absence of residues, (ii) simultaneous treatment of diverse pollutant mixtures, (iii) broad range, and (iv) ease of operation. Besides, the low cost, high abundance and safety of $\mathrm{TiO}_{2}$ make this compound the most frequently selected catalyst (Hoffmann et al., 1995; Fujishima et al., 2000; de Lasa et al., 2005). Semiconductor $\mathrm{TiO}_{2}$ generates highly oxidizing species $\left(\mathrm{O}_{2}^{-}\right.$and $\left.\mathrm{OH}\right)$ when photoexcited by UV radiation, thus catalyzing various chemical reactions, including the decomposition of organic compounds and destruction of microorganisms (Horie et al., 1996).

Photocatalysis application has been mostly intended to destroy fungi, bacteria, and spores in the air (Kakita et al., 2000; Kashige et al., 2001; Koziumi and Taya, 2002; Kühn et al., 2003; Cho et al., 2005; Pal et al., 2007; Ditta et al., 2008; Zacarías et al., 2010) though its efficiency for the inactivation of viruses contained in bioaerosols has been scarcely explored. Furthermore, only a very few studies have been focused on the combined application of UV and $\mathrm{TiO}_{2}$ in order to avoid phage dissemination in the environment. Sjogren and Sierka (1994) were able to reduce the titer of a ms2 phage (specific for Escherichia coli) suspension by a factor of 10 after $10 \mathrm{~min}$ of irradiation at $2 \mathrm{~mW} / \mathrm{m}^{2}$ in the presence of $\mathrm{TiO}_{2}$ in a continuously stirred batch reactor. Regarding phages infecting LAB, Kakita et al. (2000) have reported the inactivation of phage PL-1 (L. casei) by using a ceramic preparation coated with a mixture of oxides including $\mathrm{TiO}_{2}$ and AgO. The experiment was conducted in liquid medium and the suspended phages were subjected to irradiation with black-light (BL; 300-400 nm) in the presence of $\mathrm{TiO}_{2}$ thin film. These authors demonstrated the conversion of the virions into inactivated ghost particles, having an empty head without DNA. Later, Kashige et al. (2001) investigated the PL-1 phage inactivation mechanism; the authors found that the genome DNA inside the phage capsids was fragmented, suggesting a previous damage to the capsid protein by active oxygen species generated in the $\mathrm{TiO}_{2}$ film-settled aqueous medium under $\mathrm{BL}$. The generation of both superoxide anions $\left(\mathrm{O}_{2}^{-}\right)$and hydroxyl radicals $(\cdot \mathrm{OH})$ in the aqueous medium was verified by chemical analysis, whereas electrophoresis confirmed a considerable phage genome DNA fragmentation.

More recently, $\mathrm{TiO}_{2}$ photocatalysis was reported as a feasible methodology for the inactivation of phages infecting several LAB species, since this technology seemed to be very efficient to this purpose (Briggiler Marcó et al., 2009, 2011). To our knowledge, these studies are the first ones referring photocatalysis (UV radiation and $\mathrm{TiO}_{2}$ ) applied to phages in bioaerosols. The laboratory reactor used by Briggiler Marcó et al. (2009, 2011) consists of an UV-A radiation emitting system (wavelength range of $300-420 \mathrm{~nm}$, maximum emission at about $350 \mathrm{~nm}$ ), an irradiation chamber, and a support to hold the $\mathrm{TiO}_{2}$-coated borosilicate glass plates (Zacarías et al., 2010). The photocatalytic inactivation was applied on phage suspensions $\left(10^{7}\right.$ plaque forming units $(\mathrm{PFU}) / \mathrm{ml}$ ) prepared in distilled water. Phage suspensions were taken in the $\mathrm{TiO}_{2}$-coated plates, further covered with a borosilicate glass to create a thickness similar to bioaerosol drops, and finally irradiated in a chamber with UV light for a maximum period of $3 \mathrm{~h}$. Very dissimilar behaviors were demonstrated by each bacteriophage under the same photocatalytic treatment. For instance, undetectable counts $(<10 \mathrm{PFU} / \mathrm{ml})$ were achieved for phage BYM after $45 \mathrm{~min}$ of exposure, but $60 \mathrm{~min}$ were necessary to attain similar results $(<50 \mathrm{PFU} / \mathrm{ml})$ for phages ATCC 8014-B1 and ATCC 8014-B2. Likewise, undetectable counts $(<10 \mathrm{PFU} / \mathrm{ml})$ of phages $\mathrm{J}-1$ and QF9 particles were reached after $120 \mathrm{~min}$ of exposure. Contrarily, phages ATCC 15807-B1 and $\mathrm{Ib}_{3}$ were able to resist up to $180 \mathrm{~min}$ of treatment, exhibiting viability losses of only 1.2 log orders. A similar performance was demonstrated by phage MLC-A, with a loss of viable particles of only $2.4 \mathrm{log}$ orders after $120 \mathrm{~min}$ of exposure, (Briggiler Marcó et al., 2009, 2011). Regarding the photocatalytic inactivation efficiency $\left(\eta_{\mathrm{abs}}\right)$, values calculated by the authors differed in more than two-log orders among all the phages tested (Table 3). The highest inactivation efficiency was experimented by the bacteriophage ATCC 8014-B2 ( $\eta_{\mathrm{abs}}=4.244 \times 10^{-11} \mathrm{PFU} /$ photon$)$, whereas the lowest was that calculated for the phage $\operatorname{Cb} 1 / 342\left(\eta_{\mathrm{abs}}=0.171 \times 10^{-12} \mathrm{PFU} /\right.$ photon $)$. Besides, the authors observed that related phages, lytic for the same strain and morphologically similar, evidenced different behavior under the same conditions of photocatalytic inactivation. Attempting to explain these results, a dissimilar stability of viral proteins against the absorbed radiation energy was postulated. Considering the capsomers as a protective shield for viral DNA against the damage caused by the photocatalysis, thus different primary and conformational structure of capsid proteins would be relevant factors affecting the resulting inactivation kinetics (Briggiler Marcó et al., 2011). Articles focusing on the photocatalytic inactivation of microorganisms and or viruses hardly report their efficiency in terms of photons absorbed. In this sense, the only known study concerning $\mathrm{TiO}_{2}$ photocatalytic inactivation expressed in terms of photons absorbed was applied on bacterial cells, specifically on E. coli suspensions (Marugán et al., 2008) and the kinetic analysis was reported. An apparent photonic efficiency in the order of $10^{-11} \mathrm{CFU} /$ photon was calculated by the authors for the maximum E. coli disinfection rate achieved during the experiments. Comparable inactivation orders (of approximately $10^{-11} \mathrm{PFU} /$ photon) were obtained by Briggiler Marcó et al. (2009) when analyzing inactivation efficiency of dairy bacteriophages, showing Lb. plantarum phage ATCC 8014-B2 the highest inactivation efficiency (Table 3).

Briggiler Marcó et al. (2009, 2011) demonstrated the efficiency of the photocatalysis as a new methodology to be applied in dairies, where $\mathrm{LAB}$ represent the target of bacteriophage attacks. In comparison to the UV-C and $\mathrm{UV}-\mathrm{C} / \mathrm{TiO}_{2}$ units currently available in the market for the environmental air purification (Kover Synergy, 2010; Novapure, 2010), the UV-A radiation assayed by the authors has the advantage of safe use, thus allowing their application for long periods even in the presence of personnel. Additional research, particularly focused on the photocatalysis inactivation mechanism and the method efficiency, are indispensable for the design of equipment to be used in industrial environments, either in plants or in laboratories. 
Table 3 | Efficiency of photocatalytic inactivation of dairy bacteriophages (data adapted from Briggiler Marcó et al., 2011).

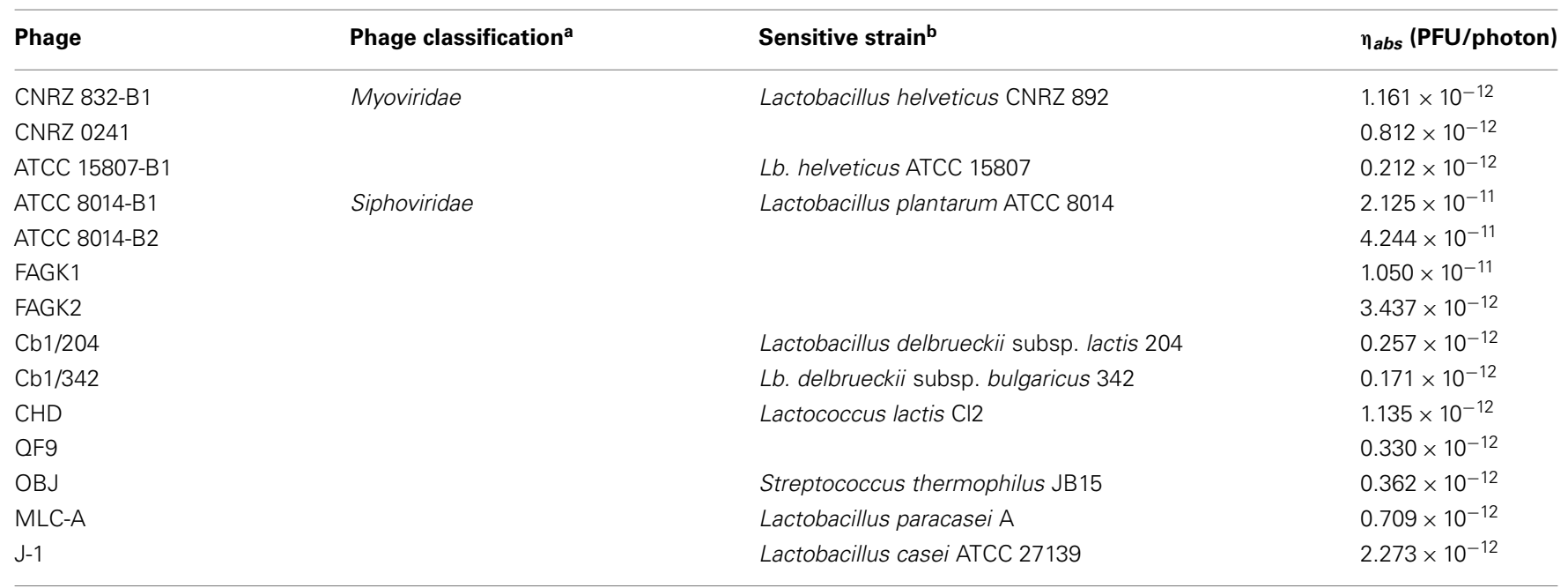

${ }^{a}$ Classification of the International Committee on Taxonomy of Viruses (ICTV) as illustrated by Ackermann (2007).

${ }^{b}$ CNRZ, Centre National de la Recherche Zootechnique. ATCC, American Type Culture Collection, Manassas, VA, USA.

$\eta_{\text {abs }}$, photocatalytic inactivation efficiency. PFU, plaque forming units.

\section{HIGH-PRESSURE TREATMENTS}

Thermal treatments such as pasteurization and sterilization were traditionally used in food industry for assuring safety and longer shelf-life of food products. Although they are efficient and economical processes to inactivate microorganisms, they can cause undesirable protein denaturation, non-enzymatic browning, and loss of vitamins and volatile flavor compounds. Bearing in mind the idea of avoiding undesirable consequences of heating, in the last years considerable efforts were focused on the development of novel non-thermal preservation processes. Among them, highpressure processing is one of the most promising, because it combines maximal retention of the chemical and physicochemical product properties with efficient germ reduction (Lado and Yousef, 2002; Diels and Michiels, 2006). The most studied and applied pressure-based processes are high hydrostatic pressure (HHP) and high-pressure homogenization ( $\mathrm{HPH})$. Although the apparent similarities between both technologies, they have some relevant differences that should be pointed out. First of all, they have very dissimilar exposure time; this parameter abruptly diminishes from a few minutes in HHP to a second or less in $\mathrm{HPH}$ (Wuytack et al., 2002). HPH is a high hydrodynamic process during which the fluid is forced to pass through a small orifice and then subjected to an ultra-rapid decompression. The sudden fall in the local pressure of the fluid at constant temperature lead to the nucleation and growth of vapor bubbles (or cavities) within the body of liquid, the collapse of which could transmit several localized forces to surfaces or particles, including the microbial cell (Middelberg, 1995). On the other hand, HHP systems consist of a pressure vessel, the pressure transmission fluid (usually water) and one or more pressurizing pumps. The packaged food is loaded into the vessel, the top is closed and the fluid is pumped into the vessel from the bottom. When the desired pressure is reached, pumping is stopped, valves are closed and the pressure is maintained without further need for energy input. The pressure is rapidly and uniformly transmitted throughout the pressure fluid and the food. The high pressure is applied isostatically so that all parts of the food are subjected to the same pressure at exactly the same time. In the case of liquids, such as fruit juices, the whole vessel can be filled with the juice, which becomes itself the pressure transmission fluid (Patterson, 2005).

Homogenization was developed many years ago with the main purpose of enhancing the texture, taste, flavor, and shelf-life of food emulsions, particularly dairy products like milk and cream butter. As the consumers began to claim for more "natural" and fresh foods with improved stability, safety and extended shelf-life, a new generation homogenizers was consequently developed, giving as a result the origin of HPH (Diels and Michiels, 2006). Besides the food industry, HPH is frequently applied in the pharmaceutical, cosmetic, and chemical industries for the preparation or stabilization of emulsions and suspensions, or to yield viscosity changes in products (Floury et al., 2004). HPH-treated milk seemed to be very convenient to improve cheese quality and physicochemical properties of fermented milks as well (Burns et al., 2008). HPH could be also applied to cell disruption of yeasts and bacteria, thus causing a partial inactivation of the microbial population and allowing the release of intracellular components (Guerzoni et al., 1999). As a consequence, HPH has been regarded as an alternative to other processes commonly applied for the inactivation of pathogenic and spoiling microorganisms (heat, sterilization, and irradiation) (Diels et al., 2005; Diels and Michiels, 2006).

Viral inactivation by HPH treatments was not profoundly studied, especially when distinctively speaking of bacteriophages (Moroni et al., 2002; Diels and Michiels, 2006; Capra et al., 2009b; D'Souza et al., 2009). As it was previously mentioned, raw milk is regarded as the main source of phages entering to the dairies, some of them possessing a remarkable thermal resistance (Capra et al., 2004; Briggiler Marcó et al., 2009). $\mathrm{HPH}$ could be therefore used as an unconventional treatment 
alternative to heat. Nevertheless, only a few reports are available in the bibliography. By using electron microscopy, Moroni et al. (2002) observed that HPH-treated lactococcal phages were possibly inactivated by the loss of genetic material from fragmented phage heads. Either total or partial loss of phage tails was also observed, rendering them incapable of adsorption to the bacterial cell wall. Results obtained by the authors demonstrated a statistically significant difference in sensitivity to $\mathrm{HPH}$ between the two morphology-types of phages: prolate-headed (phage c2) and isometric-headed (phages sk1 and ul36), being the prolate head less stable than the isometric one. More recently, phages infecting several species of lactic and probiotic bacteria were also studied. Amongst them, two temperate $L b$. paracase $i$ phages (i $L p 84$ and i $L p 1308$ ) showed a logarithmic reduction of viability along with the successive passes at $100 \mathrm{MPa}$ when suspended in RSM (Mercanti et al., 2012). For these phages, falls of 4 and $4.5 \log$ orders were observed, respectively, after five passes at $100 \mathrm{MPa}$ (Figure 2). These results were similar to those previously obtained for phages MLC-A (specific for $L b$. paracasei), ATCC 8014-B1 ( Lb. plantarum), and CNRZ 832-B1 (Lb. helveticus) subjected to the same experimental conditions (Capra et al., 2009b), observing viability losses of 3.8, 3.75, and 2.0 log orders, respectively. In turn, phages MLC-A8 ( $L b$. casei), BYM ( $L b$. delbrueckii), ALQ13.2 (S. thermophilus), QP4 and QF12 (L. lactis) were not detected after only five passes at $100 \mathrm{MPa}$ through the high-pressure homogenizer. It is interesting to emphasize that related phages MLC-A and MLC-A8, lytic for the same probiotic $L b$. paracasei strain, showed remarkably different behavior after $\mathrm{HPH}$ treatment, being the former more resistant than the latter. In addition, $\mathrm{HPH}$ treatments applied to different initial concentrations of the same phage rendered dissimilar inactivation efficiency. Contrarily to earlier reported results (Moroni et al., 2002; Capra et al., 2009b), working specifically with phage MLC-A, found that the higher the initial phage load, the greater the reduction achieved. On the other hand, bacteriophage inactivation rate showed to be proportional to both applied pressure and number of passes. Concerning the influence of suspension media (milk, whey permeate, buffer), results were very dependent on each phage. Although some authors (Moroni et al., 2002) reported diminished $\mathrm{HPH}$ effectiveness in milk and whey permeate, no clear protective effect for any of the assayed media was detected by Capra et al. (2009b).

Similarly to HPH, HHP has been proposed as an alternative to the thermal treatments applied in food preservation (Patterson, 2005). Advantages of HHP (preservation of the fresh taste and nutrient content, among others) in comparison to heat processes are comparable to those previously presented for HPH. Besides these advantages, effectiveness of HHP in inactivating different microbial species has been reported (Ananta and Knorr, 2009). Regarding bacteriophage inactivation, scarce data are available, although some authors have documented HHP inactivation of dairy phages. Specifically, L. lactis phages P001 and P008, suspended in enriched M17-broth, were treated at up to $600 \mathrm{MPa}$ (Müller-Merbach et al., 2005). Both phages are commonly found in German dairy plants, being representative of c2 (prolate head) and 936 (isometric head) species, respectively. The isometric phage P008 was considerably more resistant, with a 5 log order reduction after $2 \mathrm{~h}$ at $600 \mathrm{MPa}$, whereas the same titer reduction was

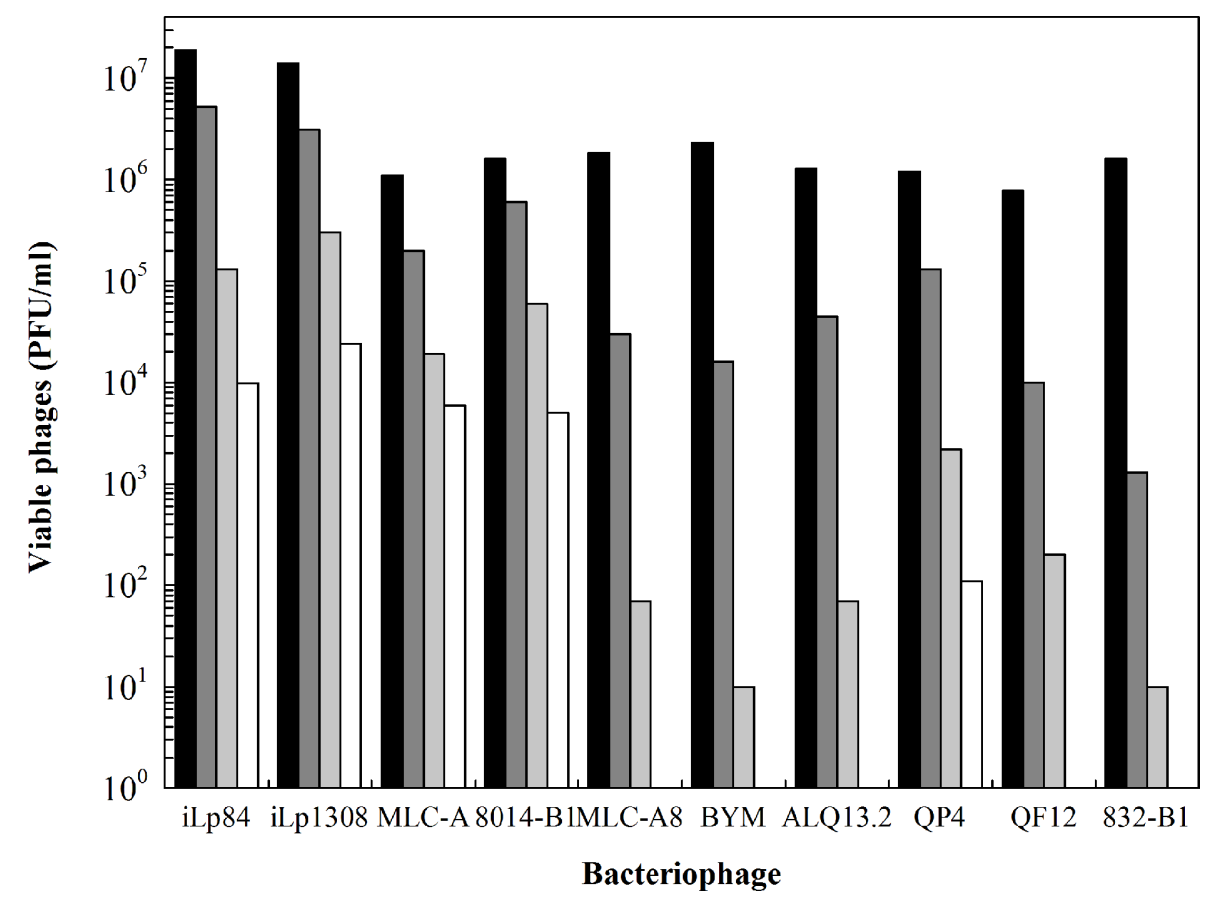

FIGURE 2 | Viability of dairy bacteriophages after multi-pass high-pressure homogenization treatments at $100 \mathrm{MPa}$ in reconstituted skim milk. Values correspond to viable phage particles
(PFU/ml) of ( $\square$ ) untreated samples, and after ( $\square$ ) one, ( $\square$ ) three, and ( $\square$ ) five passes. Data adapted from Capra et al. (2009b) and Mercanti et al. (2012). 
obtained for prolate phage P001 during the pressure-build-up time. The greater inactivation observed for the prolate head-phage led the authors think about a correlation between phage morphology and stability, in agreement with the previous hypothesis of Moroni et al. (2002). According to the latter authors, the long form of the prolate head make it less stable than the isometric structure, thus turning prolate head-phage particle more sensitive to high-pressure treatments.

\section{CONCLUSION}

Phage control measures should be focused on avoiding dissemination of phages, so as to maintain their titers under critical levels. Diverse chemical and physical treatments industrially employed for sanitization showed different rates of efficiency on phage inactivation. Considering thermal treatments, either LTLT or HTST pasteurization conditions would not assure a complete inactivation of phage particles, especially of those very thermo-resistant, and even $90^{\circ} \mathrm{C}$ were not enough to inactivate some dairy phages.

\section{REFERENCES}

Ackermann, H.-W. (2007). 5500 Phages examined in the electron microscope. Brief review. Arch. Virol. 152, 227-243.

Alatossava, T., and Pythilä, M. J. (1980). Characterization of a new Lactobacillus lactis bacteriophage. IRCS Med. Sci. 8, 297-298.

Ananta, E., and Knorr, D. (2009). Comparison of inactivation pathways of thermal or high pressure inactivated Lactobacillus rhamnosus ATCC 53103 by flow cytometry analysis. Food Microbiol. 26, 542-546.

Atamer, Z., Ali, Y., Neve, H., Heller, K. J., and Hinrichs, J. (2011). Thermal resistance of bacteriophages attacking flavour-producing dairy Leuconostoc starter cultures. Int. Dairy J. 21, 327-334.

Atamer, Z., Dietrich, J., MullerMerbach, M., Neve, H., Heller, K. J., and Hinrichs, J. (2009). Screening for and characterization of Lactococcus lactis bacteriophages with high thermal resistance. Int. Dairy J. 19, 228-235.

Atamer, Z., Dietrich, J., Neve, H., Heller, K. J., and Hinrichs, J. (2010). Influence of the suspension media on the thermal treatment of mesophilic lactococcal bacteriophages. Int. Dairy J. 20, 408-414.

Binetti, A. G., and Reinheimer, J. A. (2000). Thermal and chemical inactivation of indigenous Streptococcus thermophilus bacteriophages isolated from Argentinian dairy plants. J. Food Prot. 63, 509-515.

Briggiler Marcó, M., De Antoni, G., Reinheimer, J. A., and Quiberoni, A. (2009). Thermal, chemical and photocatalytic inactivation of Lactobacillus plantarum bacteriophages. J. Food Prot. 72, 1012-1019.

Briggiler Marcó, M., Quiberoni, A. del L., Negro, A. C., Reinheimer, J. A., and Alfano, O. M. (2011). Evaluation of the photocatalytic inactivation efficiency of dairy bacteriophages. Chem. Eng. J. 172, 987-993.

Burns, P., Patrignani, F., Serrazanetti, D., Vinderola, G. C., Reinheimer, J. A., Lanciotti, R., and Guerzoni, M. E. (2008). Probiotic Crescenza cheese containing Lactobacillus casei and Lactobacillus acidophilus manufactured with high-pressure homogenized milk. J. Dairy Sci. 91, 500-512.

Buzrul, S., Öztürk, P., Alpas, H., and Akcelik, M. (2007). Thermal and chemical inactivation of lactococcal bacteriophages. LWT Food Sci. Technol. 40, 1671-1677.

Capra, M. L., Binetti, A. G., Mercanti, D. J., Quiberoni, A., and Reinheimer, J. A. (2009a). Diversity among Lactobacillus paracasei phages isolated from a probiotic dairy product plant. J. Appl. Microbiol. 107, 1350-1357.

Capra, M. L., Patrignani, F., Quiberoni, A. del L., Reinheimer, J. A., Lanciotti, R., and Guerzoni, M. E. (2009b). Effect of high pressure homogenization on lactic acid bacteria phages and probiotic bacteria phages. Int. Dairy J. 19, 336-341.

Capra, M. L., Quiberoni, A., and Reinheimer, J. A. (2004). Thermal and chemical resistance of Lactobacillus casei and Lactobacillus paracasei bacteriophages. Lett. Appl. Microbiol.38, 499-504.

Capra, M. L., Quiberoni, A. L., Ackermann, H. W., Moineau, S., and Reinheimer, J. A. (2006). Characterization of a new virulent phage

Among biocides, only peracetic acid remains the only fully reliable option for phage destruction, though two new products seem promising for this purpose. Pioneering technologies on phage inactivation involve photocatalysis and high-pressure treatments. The former attained optimistic results until now and appears to be suitable for diminishing viable phages suspended in the air but, however, further research is needed. High-pressure treatments were barely tested for phage inactivation as well; they would fairly preserve cheese-making aptitude of milk, in contrast to strong thermal treatments, but tested phages exhibited in general a high resistance to high pressure. Anyhow, two or more inactivating strategies (maybe combining non-thermal with thermal processes) should be applied either in parallel or consecutively to obtain better results. Future efforts should be directed to determine the best combinations which permit generating a synergistic effect and thus softening the strength of each individual treatment while accomplishing the highest phage-killing activity possible.

(MLC-A) of Lactobacillus paracasei. J. Dairy Sci. 89, 2414-2423.

Cho, M., Chung, H., Choi, W., and Yoon, J. (2005). Different inactivation behaviors of MS-2 phage of Escherichia coli in $\mathrm{TiO} 2$ photocatalytic disinfection. Appl. Environ. Microbiol. 71, 270-275.

Cibsa. (2011). Clorina F. Available at: http://www.cibsaweb.com.ar/ productos.html [accessed August 15, 2011].

Daoust, D. R., El-Bisi, H. M., and Litsky, W. (1965). Thermal destruction kinetics of lactic streptococcal bacteriophage. Appl. Microbiol. 13, 478-485.

de Lasa, H., Serrano, B., and Salaices, M. (2005). Photocatalytic Reaction Engineering. New York: Springer.

Diels, A. M. J., Callewaert, L., Wuytack, E. Y., Masschalck, B., and Michiels, C. W. (2005). Inactivation of Escherichia coli by highpressure homogenization is influenced by fluid viscosity but not by water activity and product composition. Int. J. Food Microbiol. 101, 281-291.

Diels, A. M. J., and Michiels, C. W. (2006). High pressure homogenization as a non thermal technique for the inactivation of microorganisms. Crit. Rev. Microbiol. 32, 201-216.

Ditta, I. B., Steele, A., Liptrot, C., Tobin, J., Tyler, H., Yates, H. M., Sheel, D. W., and Foster, H. A. (2008). Photocatalytic antimicrobial activity of thin surface film of $\mathrm{TiO} 2$, $\mathrm{CuO}$ and $\mathrm{TiO} 2 / \mathrm{CuO}$ dual layers on Escherichia coli and bacteriophage T4. Appl. Microbiol. Biotechnol. 79, 127-133.

D'Souza, D. H., Su, X., Roach, A., and Harte, F. (2009). High-pressure homogenization for the inactivation of human enteric virus surrogates. $J$. Food Prot. 72, 2418-2422.

Ebrecht, A. C., Guglielmotti, D. M., Tremmel, G., Reinheimer, J. A., and Suárez, V. B. (2010). Temperate and virulent Lactobacillus delbrueckii bacteriophages: comparison of their thermal and chemical resistance. Food Microbiol. 27, 515-520.

Ecolab. (2011). Vortexx - material safety data sheet. Available at: http://www. ecolab.com/initiatives/foodsafety/ AST/Images/26618-3\%20Vortexx \%20CS\%20FRONT.pdf [accessed September 9, 2011].

Everson, T. C. (1991). Control of phages in the dairy plant. Bull. Int. Dairy Fed. 263, 4-11.

Floury, J., Bellettre, J., Legrand, J., and Desrumaux, A. (2004). Analysis of a new type of homogenizer. A study of the flown pattern. Chem. Eng. Sci. 59, 843-853.

Fujishima, A., Rao, T. N., and Tryk, D. A. (2000). Titanium dioxide photocatalysis. J. Photochem. Photobiol. C Photochem. Rev. 1, 1-21.

Gehr, R., Wagner, M., Veerasubramanian, P., and Payment, P. (2003). Disinfection efficiency of peracetic acid, UV and ozone after enhanced primary treatment of municipal wastewater. Water Res. 37, 4573-4586.

Guerzoni, M. E., Vannini, L., ChavesLópez, C., Lanciotti, R., Suzzi, G., and Gianotti, A. (1999). Effect of high pressure homogenization on microbial and chemico-physical characteristics of goat cheeses. J. Dairy Sci. 82, 851-862.

Hiatt, C. W. (1964). Kinetics of the inactivation of viruses. Bacteriol. Rev. 28 , 150-163. 
Hoffmann, M. R., Martin, S. T., Choi, W., and Bahnemann, D. W. (1995). Environmental applications of semiconductor photocatalysis. Chem. Rev. 95, 69-96.

Horie, Y., David, D. A., Taya, M., and Tone, S. (1996). Effects of light intensity and titanium dioxide concentration on photocatalytic sterilization rates of microbial cells. Ind. Eng. Chem. Res. 35, 3920-3926.

Josephsen, J., and Neve, H. (1998). "Bacteriophages and lactic acid bacteria," in Lactic Acid Bacteria. Microbiology and Functional Aspects, Vol. 7, eds S. Salminen and A. von Wright (New York: Marcel Dekker, Inc.), 385-436.

Kakita, Y., Obuchi, E., Nakano, K., Murata, K., Kuroiwa, A., Miake, F., and Watanabe, K. (2000). Photocatalytic inactivation of Lactobacillus PL-1 phage by a thin of titania. Biocontrol Sci. 5, 73-79.

Kashige, N., Kakita, Y., Nakashima, Y., Miake, F., and Watanabe, K. (2001). Mechanism of the photocatalytic inactivation of Lactobacillus casei phage PL-1 by titania thin film. Curr. Microbiol. 42, 184-189.

Kiuru, V. J., and Tybeck, E. (1955). Characteristics of bacteriophages actives against lactic acid bacteria in Swiss cheese. Suom. Kemistil. B. 28, 56-62.

Kover Synergy. (2010). UV Sterile Air System. Available at: http://www. koveritalia.com/uv_steril_air_syst em.html [accessed August 25, 2011].

Koziumi, Y., and Taya, M. (2002). Kinetic evaluation of biocidal activity of titanium dioxide against phage MS- 2 considering interaction between the phage and photocatalyst particles. Biochem. Eng. J. 12, 107-116.

Kühn, K. P., Chaberny, I. F., Massholder, K., Stickler, M., Benz, V. W., Sonntag, H. G., and Erdinger, L. (2003). Disinfection of surfaces by photocatalytic oxidation with titanium dioxide and UVA light. Chemosphere 53, 71-77.

Lado, B. H., and Yousef, A. E. (2002). Alternative technologies: efficacy and mechanisms. Microbes Infect. 4, 433-440.

Maillard, J. Y., Beggs, T. S., Day, M. J., Hudson, R. A., and Russel, A. D. (1993). Effect of biocides on Pseudomonas aeruginosa phage F116. Lett. Appl. Microbiol. 17, 167-170.

Maillard, J. Y., Beggs, T. S., Day, M. J., Hudson, R. A., and Russel, A. D. (1996a). Damage to Pseudomonas aeruginosa PAO1 bacteriophage F116 DNA by biocides. $J$. Appl. Bacteriol. 80, 540-544.

Maillard, J. Y., Beggs, T. S., Day, M. J., Hudson, R. A., and Russel, A. D. (1996b). The effect of biocides on protein of Pseudomonas aeruginosa PAO bacteriophage F116. J. Appl. Bacteriol. 80, 291-295.

Maillard, J. Y., Hann, A. C., Baubet, V., and Perrin, R. (1998). Efficacy and mechanisms of action of sodium hypochlorite on Pseudomonas aeruginosa PAO1 phage F116. J. Appl. Microbiol. 85, 925-932.

Marugán, J., van Grieken, R., Sordo, C., and Cruz, C. (2008). Kinetics of photocatalytic disinfection of Escherichia coli suspensions. Appl. Catal. B 82, 27-36.

Mercanti, D. J., Guglielmotti, D. M., Patrignani, F., Reinheimer, J. A., and Quiberoni, A. (2012). Resistance of two temperate Lactobacillus paracasei bacteriophages to high pressure homogenization, thermal treatments and chemical biocides of industrial application. Food Microbiol. 29, 99-104.

Middelberg, A. P. J. (1995). Processscale disruption of microorganisms. Biotechnol. Adv. 13, 491-551.

Moroni, O., Jean, J., Autret, J., and Fliss, I. (2002). Inactivation of lactococcal bacteriophages in liquid media using dynamic high pressure. Int. Dairy J. 12, 907-913.

Müller-Merbach, M., Rauscher, T., and Hinrichs, J. (2005). Inactivation of bacteriophages by thermal and highpressure treatment. Int. Dairy J. 15, 777-784.

Neve, H. (1996). “Bacteriophage,” in Dairy Starter Cultures, eds T. M. Cogan and J.-P. Accolas (New York: VCH Publishers. Inc.), 157-189.

Neve, H., Krusch, U., and Teuber, M. (1989). Classification of virulent bacteriophages of $S$. salivarius spp. thermophilus isolated from yoghurt and Swiss-type cheese. Appl. Microbiol. Biotechnol. 30, 624-629.
Nicholds, A., and Wolf, J. (1945). The heat resistance of the bacteriophages of cheese starter with observations on the estimation of phages concentration. J. Dairy Res. 14 93-100.

Novapure. (2010). Air Titan Air Purifiers. Available at: http://www. morphicenvirotech.com/novapure/ [accessed August 30, 2011].

Pal, A., Pehkonen, S. O., Yu, L. E., and Ray, M. B. (2007). Photocatalytic inactivation of Gram-positive and Gram-negative bacteria using fluorescent light. J. Photochem. Photobiol. A Chem. 186, 335-341.

Patterson, M. F. (2005). Microbiology of pressure-treated foods. J. Appl. Microbiol. 98, 1400-1409.

Quiberoni, A., Guglielmotti, D., Binetti, A., and Reinheimer, J. (2004). Characterization of three Lactobacillus delbrueckii subsp. bulgaricus phages and the physicochemical analysis of phage adsorption. J. Appl. Microbiol. 96, 340-351.

Quiberoni, A., Guglielmotti, D. M. and Reinheimer, J. A. (2003). Inactivation of Lactobacillus delbruecki bacteriophages by heat and biocides. Int. J. Food Microbiol. 84 51-62.

Quiberoni, A., Suárez, V. B., and Reinheimer, J. A. (1999). Inactivation of Lactobacillus helveticus bacteriophages by thermal and chemical treatments. J. Food Prot. 62, 894-898.

Quiberoni, A., Tremblay, D., Ackermann, H. W., Moineau, S., and Reinheimer, J. A. (2006). Diversity of Streptococcus thermophilus phages in a large production cheese factory in Argentina. J. Dairy Sci. 89, 3791-3799.

Schröder, W. (1984). Peracetic acid. Disinfectant for the foodstuff industry. Brauwelt Int. 1, 115-120.

Séchaud, L., Rousseau, M., Fayard, B. Callegari, M. L., Quénée, P., and Accolas, J.-P. (1992). Comparative study of 35 bacteriophages of $L$. helveticus: morphology and host range. Appl. Environ. Microbiol. 58, 1011-1018.

Sjogren, J. C., and Sierka, R. A. (1994). Inactivation of phage MS2 by ironaided titanium dioxide photocatalysis. Appl. Environ. Microbiol. 60, 344-347.
Soukoulis, C., Panagiotidis, P., Koureli, R., and Tzia, C. (2007). Industrial yogurt manufacture: monitoring of fermentation process and improvement of final product quality. $J$. Dairy Sci. 90, 2641-2654.

Suárez, V. B., and Reinheimer, J. A. (2002). Effectiveness of thermal treatments and biocides in the inactivation of Argentinian Lactococcus lactis phages. J. Food Prot. 65, 1756-1759.

Svensson, V., and Christiansson, A (1991). Methods for phage monitoring. Bull. Int. Dairy Fed. 263, 29-39.

Wuytack, E. Y., Diels, A. M. J., and Michiels, C. W. (2002). Bacterial inactivation by high pressure homogenization and high hydrostatic pressure. Int. J. Food Microbiol. 77, 205-212.

Zacarías, S. M., Vaccari, M. C., Alfano, O. M., Irazoqui, H. A., and Imoberdorf, G. E. (2010). Effect of the radiation flux on the photocatalytic inactivation of spores of Bacillus subtilis. J. Photochem. Photobiol. A Chem. 214, 171-180.

Conflict of Interest Statement: The authors declare that the research was conducted in the absence of any commercial or financial relationships that could be construed as a potential conflict of interest.

Received: 19 September 2011; paper pending published: 10 November 2011; accepted: 28 December 2011; published online: 11 January 2012.

Citation: Guglielmotti DM, Mercanti $D J$, Reinheimer JA and Quiberoni AdL (2012) Review: efficiency of physical and chemical treatments on the inactivation of dairy bacteriophages. Front. Microbio. 2:282. doi: 10.3389/fmicb.2011.00282

This article was submitted to Frontiers in Food Microbiology, a specialty of Frontiers in Microbiology.

Copyright (C) 2012 Guglielmotti, Mercanti, Reinheimer and Quiberoni. This is an open-access article distributed under the terms of the Creative Commons Attribution Non Commercial License, which permits non-commercial use, distribution, and reproduction in other forums, provided the original authors and source are credited. 